\title{
Clinical Course of COVID-19 in a Thalassemia Major Patient who Underwent Haematopoietic Stem Cell Transplantation
}

\section{Hematopoetik Kök Hücre Nakli Yapılmış Bir Talasemi Majör Hastasında COVID- 19 'un Klinik Seyri}

\author{
(D) Aziz Ahmad HAMIDí11, io Yıldız ULU11, io Habibullah AKTAŞ2
}

${ }^{1}$ Karabük Medical School, Infectious Diseases and Clinical Microbiology, Karabük, Turkey

${ }^{2}$ Karabük University Karabük Faculty of Medicine, Department of Dermatology, Karabük, Turkey

\begin{abstract}
We herein reported the course of Coronavirus diasease-19 (COVID-19) in a 21-year-old patient with thalassemia majo rdisease. The patient who underwent haematopoietic stem cell transplantation in 2013 and developed alloimmunization, presented with high fever and weakness. His parents have been recently diagnosed with COVID-19. COVID-19 diagnosis was confirmed by real time-polymerase chain reaction (RT-PCR) method in the nasopharyngeal swab sample of the patient while his thorax computed tomography was not found in favor of pneumonia. The patient was treated with hydroxychloroquine $2 \times 200 \mathrm{mg}$ and Favipravir 3x600mg. The temperature fell with in three days. The clinical condition of the patient improved rapidly. On the 20th day, he did not have any symptom with a recovery of anemia and lymphopenia, but the RT-PCR result was stil positive. In this case report, we wanted to point out that the course of the COVID-19 is unexpectedly mild in such a patient with thalassemia major.
\end{abstract}

Keywords: COVID-19, thalassemia major, beta-thalassemia

\section{ÖZ}

Talasemi major hastalığı olan 21 yaşındaki bir hastada Koronavirüs hastalığı-19'un (COVID-19) klinik seyri sunulmuştur. 2013 yılında hematopoetik kök hücre nakli yapılmış ve alloimmunizasyon gelişmiş hasta, yüksek ateş ve halsizlik şikayeti ile başvurdu. Yakın zamanda anne ve babası COVIDD-19 tanısı almıştı. Toraks tomografisinde pnömoni lehine bulgu saptanmayan hastanın COVID-19 tanısı nazofarengeal sürüntü örneğinde gerçek zamanlı polimeraz zincir reaksiyonu (RT-PCR) yöntemiyle doğrulandı. Hastaya hidroksiklorokin 2×200 mg ve favipravir 3×600 mg tedavisi başlandı. Ateşi üç gün sonra düştü. Hastanın klinik durumu hızla iyileşti. Anemi ve lenfopenisi düzelen hastanın, tedavinin 20. gününde herhangi bir semptomu yoktu. Ancak RT-PCR sonucu hala pozitif idi. $\mathrm{Bu}$ olgu sunumuyla talasemi majörü olan bir hastada, COVID-19'un beklenmedik biçimde hafif seyrettiğine dikkati çekmek istedik.

Anahtar Sözcükler: COVID-19, talasemi majör, beta talasemi

\section{Introduction}

Novel coronavirus infection that occured in Wuhan, China in December 2019, has spread rapidly among people and caused pandemic. After isolation and identification of virus, the causative agent was named as severe acute respiratory syndrome coronavirus-2 (SARS-CoV-2). The disease caused by the new pneumonia virus SARS- $\mathrm{CoV}-2$ was defined Coronavirus disease-2019 (COVID-19) by World Health Organisation (13). In Turkey the first COVID-19 case was detected on March 10,2020 and first death caused by SARS-CoV-2 was seen on March 15, 2020. Thalassemia is a common genetic disorder worldwide. In patients with homozygous thalassemia major, repeated transfusion and chelation treatments are required. Bone marrow transplantation offers cure oftenly when performed at first years of patient's life (4). The risk for the development 
of agranulocytosis and neutropenia is increased, especially in patients using chelation therapy. Accordingly, these patients may develop bacterial infections and sepsis. The risk for acute kidney injury, cardiac arrhythmias and cardiac failure increases during infections (5).

In this article, we present the course of COVID-19 disease in a thalassemia major patient who underwent haematopoietic stem cell transplantation and developed alloimmunisation.

\section{Case Report}

A 21-year-old man was admitted to the hospital with the complaint of fever and fatigue. It was learned that his parents who shared the same house, were hospitilized with a diagnosis of COVID-19 one day ago. The patient has a diagnosis of thalassemia major and he was performed haematopoietic stem cell transplantation and developed alloimmunisation in 2013. On admission, his body temperature was 39 degrees Celsius, systolic blood pressure $100 \mathrm{~mm} / \mathrm{Hg}$, diastolic blood pressure $60 \mathrm{~mm} / \mathrm{Hg}$ and oxygen saturation of $97 \%$ while the patient was breathing ambient air. The chest auscultation findings defined no abnormal sound (crackles, rhonchi, orwheezing). Electrocardiography was normal. Blood routine tests were hemoglobin (hgb): $5.3 \mathrm{~g} / \mathrm{dL}$, white blood cell (WBC): 1.81/L, platelet (PLT): 103,000/L, lymphocyte: 980/L, aspartate aminotransferase (AST): $23 \mathrm{U} / \mathrm{L}$, alanine aminotransferase (ALT): $10 \mathrm{U} / \mathrm{L}$, creatinine: $0.37 \mathrm{mg} /$ $\mathrm{dL}$, C-reactive protein (CRP): $8.3 \mu \mathrm{g} / \mathrm{mL}$, procalcitonin: 0.11 $\mathrm{ng} / \mathrm{mL}$, lactate dehydrogenase (LDH): $330 \mathrm{U} / \mathrm{L}$, ferritin: 1,040 $\mathrm{ng} / \mathrm{mL}$, D-dimer: $0.31 \mu \mathrm{g} / \mathrm{mL}$, total bilirubin: $6.6 \mathrm{mg} / \mathrm{dL}$, directbilirubin: $0.5 \mathrm{mg} / \mathrm{dL}$, total protein: $7.6 \mathrm{gr} / \mathrm{dL}$, albumin: 5.0 $\mathrm{g} / \mathrm{dL}$. Computed tomography of the chest revealed no finding in favor of viral pneumonia. The patient's nasopharyngeal and oropharyngeal swab test for SARS-CoV-2 by real timepolymerase chain reaction (RT-PCR) assay was positive. He was hospitilized on April 26, 2020. The treatment started with hydroxychloroquine (HCQ) $400 \mathrm{mg}$ bid loading dose for firstday, than $200 \mathrm{mg}$ bid maintenance dose for other four days. On the third day of therapy, body temperature continued as 38.4 degrees Celsius. Control blood tests were hgb: $6.9 \mathrm{gr} / \mathrm{dL}$, WBC: 1.45/L, PLT: 90,000/L, lymphocyte: 580/L, AST: 45 U/L, ALT: $25 \mathrm{U} / \mathrm{L}$, creatinine: $0.35 \mathrm{mg} / \mathrm{dL}$, CRP: $6.4 \mu \mathrm{g} / \mathrm{mL}$, procalcitonin: $0.15 \mathrm{ng} / \mathrm{mL}$, LDH: 297U/L, ferritin: $917 \mathrm{ng} / \mathrm{mL}$, D-dimer: $0.19 \mu \mathrm{g} / \mathrm{mL}$, total bilirubin: $4.3 \mathrm{mg} / \mathrm{dL}$, direct bilirubin: 0.4 $\mathrm{mg} / \mathrm{dL}$. Then, favipravir $1,600 \mathrm{mg} \mathrm{q} 12 \mathrm{~h}$ loading dose for the first day, than $600 \mathrm{mg}$ q12h maitenence dose was added to the HCQ therapy. Because of low hgb level, 2 units of erythrocyte suspension with leucocyte fitler were transfused. On the fourth day of hospitalization, he maintained normal body temperature (37 degrees Celsius). The patient's symptoms improved, and his favipravir and HQL medications were completed in 5 days. On the tenth day of hospitalization, patient's nasopharyngeal andoropharyngeal swab test for SARS-CoV-2 by RT-PCR assay was stil positive while he has completely free of symptoms. On May 5, 2020, he was discharged, and taken home quarantine for at least 14 days. SARS-CoV-2 by nasopharyngeal and oropharyngeal swab RT-PCR assay remained positive in his follow- upcheck on 15 May. Control blood tests were hgb: 8.2 gr/dL, WBC: 3960 /L, PLT: 139,000/L, lymphocyte: 1,500/L, AST: $17 \mathrm{U} / \mathrm{L}$, ALT: $11 \mathrm{U} / \mathrm{L}, \mathrm{CRP}: 0.23 \mu \mathrm{g} / \mathrm{mL}$, procalcitonin: $0.10 \mathrm{ng} / \mathrm{mL}$, LDH: $231 \mathrm{U} / \mathrm{L}$, ferritin:1,476 ng/mL, D-dimer: $0.23 \mu \mathrm{g} / \mathrm{mL}$, total bilirubin: $4.3 \mathrm{mg} / \mathrm{dL}$, directbilirubin: $0.4 \mathrm{mg} /$ dL. He was clinically wel. One week later, the RT-PCR assay was negative.

\section{Discussion}

COVID-19 causes coagulopathy, lymphopenia, thrombocytopenia and anemia with various mechanisms in the patients (2). Our patient had leukopenia, thrombocytopenia and anemia at the time of admission. This makes the patient at risk for the poor course of COVID-19. Fortunately there was no lung involvement. Iron accumulation due to frequent blood transfusion causes major complications in patients with thalassemia major. As a result of excessive irona ccumulation, complications such as growth retardation, sexual developmental delay, arrhythmia, cardiomyopathy, liver fibrosis, diabetes mellitus, hypogonadism, hypoparathyroidism and hypothyroidism (6). Our patient underwent two units of erythrocyte suspension transfusion. However, there was no need for PLT transfusion.

Ferritin is found in all cells in the body. It is especially found in macrophages and hepatocytes, which play a role in iron metabolism. In beta thalassemia cases, serum ferritin level is an indicator of iron load in the heart and liver (7). In addition, in COVID-19 cases, the high level of ferritin indicates the severity of the disease (8). The high ferritin level in our patient was thought to be due to beta thalassemia disease.

The development of alloimmunization after haematopoietic stem cell transplantation in this patient increases the tendency for both infections and thromboembolic events. However, COVID-19 was quite mild in our patient with no lung involvement. In addition, thromboembolic complications did not develop. Similarly, Motta et al. (9) presented the clinical features of 11 beta thalassemia patients who underwent COVID-19, while three patients were asymptomatic, six patients showed mild findings and one patient (accompanied by diffuse large B cell lymphoma) required non-invasive respiratory support. As a result, none of 11 patients showed death, severe acute respiratory syndrome and signs of cytokine storm (9).

SARS-CoV-2 infection has three major phases such as early infection, pulmonary involvement and systemic hyperinflammation phase (10). We observed that our patient was in the early phase of the disease (viral phase), due to the absence of pneumonia findings in the thorax CT and positivity of RT-PCR. In follow-up, the patient did not progress to the pulmonary involvment phase. The HCQ and favipravir administration may have had a positive effect in the patient. Yet in cases of thalassemia, it is necessary to identify host-related factors determinining the course of COVID-19 disease.

With this case report, we want a contribution regarding the progress of COVID-19 in thalassemia patients. 
Peer-review: Externally peer reviewed.

\section{Authorship Contributions}

Surgical and Medical Practices: A.A.H., H.A., Concept: A.A.H., H.A., Design: A.A.H., Y.U., H.A., Data Collection or Processing: A.A.H., Y.U., H.A., Analysis or Interpretation: A.A.H., Y.U., H.A., Literature Search: A.A.H., Y.U., Writing: A.A.H., Y.U., H.A.

Conflict of Interest: No conflict of interest was declared by the authors.

Financial Disclosure: This work was supported by Abdi İbrahim Pharmaceuticals.

\section{References}

1. World health organization. Coronavirus disease (covid-19) pandemic. . https://www.who.int/emergencies/diseases/novel-coronavirus-2019; 2020.

2. Huang C, Wang Y, Li X, Ren L, Zhao J, Hu Y, et al. Clinical features of patients infected with 2019 novel coronavirus in wuhan, china. Lancet 2020;395:497-506.

3. Lu H, Stratton CW and Tang YW. Outbreak of pneumonia of unknown etiology in wuhan, china: The mystery and the miracle. J Med Virol 2020;92:401-2.
4. Choudhry VP. Thalassemia minor and major: Current management. Indian J Pediatr 2017;84:607-11.

5. Roy NBA, Telfer P, Eleftheriou P, de la Fuente J, Drasar E, Shah F, et al. Protecting vulnerable patients with inherited anaemias from unnecessary death during the covid-19 pandemic. Br J Haematol 2020;189:635-9.

6. He LN, Chen W, Yang Y, Xie YJ, Xiong ZY, Chen DY, et al. Elevated prevalence of abnormal glucose metabolism and other endocrine disorders in patients with beta-thalassemia major: A meta-analysis. Biomed Res Int 2019;2019:6573497.

7. Sobhani S, Rahmani F, Rahmani M, Askari M, Kompani F. Serum ferritin levels and irregular use of iron chelators predict liver iron load in patients with major beta thalassemia: a cross-sectional study. Croat Med J 2019;60:405-13.

8. Zhou F, Yu T, Du R, Fan G, Liu Y, Liu Z, et al. Clinical course and risk factors for mortality of adult inpatients with COVID-19 in Wuhan, China: a retrospective cohort study Lancet 2020;395:1054-62.

9. Motta I, Migone De Amicis M, Pinto VM, Balocco M, Longo F, et al. Sars-cov-2 infection in beta thalassemia: Preliminary data from the italian experience. Am J Hematol 2020;95:E198-E9.

10. Siddiqi HK, Mehra MR. Covid-19 illness in native and immunosuppressed states: A clinical-therapeutic staging proposal. J Heart Lung Transplant 2020;39:405-7. 